\title{
Relationship and innovation orientation in a business-to-business context
}

\author{
G. Human* \\ School of Management Studies, University of Cape Town, \\ Private Bag, Rondebosch 7701, Cape Town, Republic of South Africa \\ Gert human@uct.ac.za \\ P. Naudé \\ Manchester Business School, United Kingdom
}

Received October 2010

\begin{abstract}
Market orientation and innovation orientation, including their relationship with firm performance, are well-debated in prevailing marketing literature. Interestingly, relationship orientation, as an extension of market orientation, is yet to be subjected to similar investigation. While relationship orientation suggests that firms should invest in building relationships with clients and suppliers to generate improved financial performance, innovation orientation proposes that customers will prefer superior and innovative products/services and it supports a learning philosophy. Torn between two shores, the result is often that practitioners are confused as to what the desired orientation for the firm should be. This paper considers the relationship of both orientations with firm performance in business-to-business (B2B) markets simultaneously, and in particular examines the mediating effect of innovation on the relationship orientation-firm performance relationship. By employing published scales for innovation and relationship orientation, cross-sectional data were collected from 181 business-to-business managers in South African firms. Confirmatory factor analysis was used to test for scale reliability and validity, while the hypothesized relationships between constructs were considered through structural equation modelling and partial least squares analysis. The paper provides valuable insights for measuring these constructs in an emerging market context and suggests a balanced approach to adopting these strategic orientations in B2B markets. The results suggest that practitioners and researchers should pay attention to both orientations simultaneously, because jointly they are associated with better firm performance.
\end{abstract}

*To whom all correspondence should be addressed.

\section{Introduction}

Since Miles and Snow (1978) introduced their typology of four strategic orientations, various alternative approaches to strategic orientation (including market orientation, product orientation, customer orientation, innovation orientation, relationship orientation, stakeholder orientation and interaction orientation) have emerged. Many authors (Laforet, 2008; Pleshko \& Nickerson, 2008; Gao, Zhou \& Yim, 2007; Moses, 2007; Leskovar-Spacapan \& Bastic, 2007; Santos-Vijande et al., 2005; Strandholm, Kumar \& Subramanian, 2004; Camelo-Ordaz, Martin-Alcasar \& Valle-Cabrera, 2003; Morgan \& Strong, 2003; Noble, Sinha \& Kumar, 2002; Luo \& Park, 2001; Deshpandé \& Farley, 2000; Dobni \& Luffman, 2000; Voss \& Voss, 2000; Morgan \& Strong, 1998; Deshpandé, Farley \& Webster, 1997; Gatignon \& Xuereb, 1997; Manu \& Sriram, 1996; Rajagopalan, 1997; Golden, Johnson \& Smith, 1995; Wright et al., 1995; McKee, Varadarajan \& Pride, 1989; Venkatraman, 1989; Robinson Jr. \& Pearce II, 1988; Doyle \& Hooley, 1992; Day \& Wensley, 1983) employ the idea of strategic orientation to described the overall dominant logic that represents a firm's competitive posture based on its conceptualisation of the internal and external situation and/or environment. Although it appears conceivable that a firm might adopt multiple strategic orientations, the idea of market orientation (Kohli \& Jaworski, 1990; Narver \& Slater, 1990) seems to have attracted the majority of the attention in marketing literature. In particular, many of the studies cited above demonstrate the positive relationship between market orientation and firm performance.

This paper seeks to contribute to this void in the literature by considering innovation and relationship orientation simultaneously, and to test their relationship with firm performance. In particular, the paper builds on the approach followed by Berthon, Hulbert and Pitt (2004) in its inclusion of innovation orientation, but substitutes market orientation with a measure for relationship orientation as suggested by Sin et al. (2005b). First, the paper offers literature support for the relationship between innovation orientation and firm performance, as well as the link between relationship orientation and performance. This approach assists in the identification of the constructs to be included in the study and facilitates the motivation for considering innovation and relationship orientation simultaneously. This theorisation resulted in the formulation of nine hypotheses. Next, we provide a summary of the methodology and proceed to report the results of a survey conducted amongst 181 business-to-business managers in a South African context. 
The paper concludes with managerial implications and suggestions for further research.

\section{Literature review}

Both innovation and relationship orientation receive considerable attention in management literature, and when considered separately, both concepts are demonstrated to have positive implications for business performance. While innovation orientation builds on a philosophy (Berthon, Hulbert \& Pitt, 2004) suggesting that customers will prefer superior and innovative products and services, relationship orientation builds on the philosophical grounding of market orientation that suggests understanding customer needs is the key to customers' satisfaction and firm performance. The relationship between innovation and market orientation has been the focus of many studies (Zhou et al., 2005a; Zhou, Yim, \& Tse, 2005, Berthon et al., 2004; Deshpandé \& Farley, 2004; Atuahene-Gima, 1996; Deshpandé, Farley \& Webster, 1993), but the relationship between innovation orientation and relationship orientation seems to have received less research attention. Yet, both scholarly and popular opinion often emphasize the importance of both these strategic orientations. Consequently, practitioners may receive mixed and varied messages as to which orientation might serve them best and how they might employ both approaches to enhance business performance. In this section we review the literature on relationship orientation that supports its operationalization as a multi-factor construct and the subsequent development of a measure for it. Then we turn to innovation orientation by focusing particularly on the literature that demonstrates its relation with market orientation (as a proxy for relationship orientation), as well as its relation to firm performance.

\section{Relationship orientation}

Relationship orientation was developed from the platform provided by the earlier work on market orientation because the philosophy of business has shifted from a production orientation to a selling orientation, then to a marketing orientation, and finally to a relationship orientation (Terblanche, 2005; Grönroos, 1989; Gruen, 1995). According to Sin et al. (2005b), relationship orientation received contributions from the literature in service marketing, sales (selling) management, marketing channels, interaction and networks, and the guanxi literature in China. Various studies in the field of marketing have each referred to the term relationship orientation or relationship marketing orientation from a different theoretical viewpoint, unit of analysis, and with alternative construct definitions. Three approaches seem to emerge. The first appears to focus on the building blocks of a relationship and conceptualises relationship orientation at a "dyadic level by putting the buyer-seller relationship at the centre of the firm's strategic or operational thinking" (Sin et al. 2005b:186). This approach postulates that relationship orientation is a multidimensional construct consisting of six components, including: trust, bonding, communication, shared value, empathy and reciprocity. A second approach focuses on a culturally embedded model of relationship orientation and draws heavily on the organisational culture literature to examine four components of culture: values, behaviours, artifacts, and assumptions (Winklhofer, Pressey \& Tzokas, 2006). A final approach conceptualizes relationship orientation as a higher-order construct which may be indicated by four types of relationship marketing investments: communication, customization, personalization (preferential treatment) and personal relationships (Camarero, 2007). Marketing literature (Morgan \& Hunt, 1994; Palmatier, 2008) seems support the fist approach and, in addition, it also overlaps with the conceptualization by Camerero (2007). Therefore we adopted the approach by Sin et al. (2005b) and argue that relationship orientation is a multi-dimensional construct consisting of six components as indicated above. Sin et al. (2005b) confirmed the reliability and validity of a scale to measure each latent variable and refer to it as the RMO scale. In order to simplify our approach we will refer to it as relationship orientation (RO) and we offer a brief consideration of each component of RO.

\section{Trust}

Trust remains a key component of business relationships in both consumer and business markets (Palmatier et al., 2008; Palmatier, Dant \& Grewal, 2007). It is conceptualized as that component of a business relationship that determines the level to which each party feels they can rely on the integrity of the promise offered by the other party. This mutual trust is theorized (Sin et al., 2005b) to enhance the probability of continued long-term relationships between the parties. In the business-to-business marketing literature trust is often referred to as an element in personal, interorganizational and intra-organizational relationships (Fill \& Fill, 2005). Trust (inter-organizational) involves credibility (the extent to which one organization believes that another organization will undertake and complete its agreed roles and tasks) and benevolence (that the other organization will not act opportunistically, even if the conditions for exploitation are favourable). Hence, the quality of the business relationship is linked to the level of trust between the parties. Notably, commitment appears absent from the Sin et al. (2005b) conceptualization. Many authors (Morgan \& Hunt, 1994; Palmatier et al., 2008; Theron, Terblanche \& Boshoff, 2008) emphasize the importance of commitment in the same breath with trust - as a key factor in relational quality. By contrast, Sin et al. (2005b) favour bonding in their conceptualization of relationship orientation, thus qualifying the conceptualization of trust only.

\section{Bonding}

Social bonding is the bond that keeps buyer and seller together in a personal sense, and encompasses personal interactivity and feelings of personal closeness (Stanko, Bonner \& Calatone, 2007). A long-term buyer-seller relationship requires bonding because stronger personal bonds between buyers and sellers lead to a greater commitment to maintain the relationship (Sin et al., 2005b). Bonding is defined as that component of a business relationship that results in buyers and sellers acting together to attain a common goal. Hence, this conceptualization appears consistent with that of commitment mentioned above. 


\section{Communication}

According to Sin et al. (2005b), communication can be defined as the formal, as well as informal, exchanging and sharing of meaningful and timely information between buyers and sellers. This is regarded as a crucial component for the formation of cooperation and trust in a business relationship. For example, Morgan and Hunt (1994) showed that communication has a positive and indirect impact on buyer-supplier relationship commitment, while in another South African study Theron et al. (2008) observed a similar relationship between communication and relationship commitment.

\section{Shared value}

Shared value is defined as the extent to which partners have common beliefs about what behaviours, goals and policies are important, appropriate and right. It is believed to increase commitment in business relationships (Morgan \& Hunt, 1994) and is, therefore, very important. Moreover, Lai (2009) notes that in a relationship that features a high intensity of shared values there appears to be the desire by both parties to maintain the continuity of the relationship. Moreover, in situations of total interdependence, shared norms and values exert a moderating effect on the strategies that are adopted and buyers comply with sellers' requests and adopt less-opportunistic behaviours.

\section{Empathy}

Empathy is considered a necessary condition for fostering a positive relationship between two parties. According to Wang (2007), it refers to the ability to see a situation from another person's perspective. The greater the degree of empathy, the less problematic are the barriers to the development of a relationship. Sin et al. (2005b) motivate for its inclusion in their conceptualization of relationship marketing orientation from both the service marketing and the network literature. Empathy is defined (Sin et al. 2005b) as seeking to understand the desires and goals of somebody else - alternatively, those of a client. In addition, results from a study by Klemz, Boshoff and Mazibulo (2006) show that small, local and independently-owned retailers focus extensively on empathy to influence willingness to buy. Thus, emphasizing the importance of empathy in a South African business relationship context.

\section{Reciprocity}

According to Sin et al. (2005b), reciprocity is that component of a business relationship that causes either party to provide favours or make allowances at a later date. This notion is well-supported (Palmatier, 2007; Ramani \& Kumar, 2008) and is often referred to as relationshipspecific investments. Wang (2007) also noted cultural differences in the how reciprocity is perceived and compared Chinese to Western approaches. It is argued that Western societies emphasize short-term, symmetrical reciprocation in a balanced exchange relationship, whereas in Chinese culture the "return in kind" can be on a longerterm and be asymmetrical with the expectation that the relationship will last into the unforeseeable future. This serves as an alert to the measurement of reciprocity, and supports its careful consideration in an African context.

Based on these considerations, we employed the RMO Scale (Sin et al., 2005b) to gauge relationship orientation (RO) and we tested its internal reliability and construct validity in a South African context. Furthermore, the demonstrated positive relation between market orientation and firm performance (Deshpandé, Farley \& Bowman, 2004; Morgan \& Strong, 2003; Tse et al., 2003; Rajagopalan, 1997; Au \& Tse, 1995; Doyle \& Hooley, 1992; Venkatraman, 1989) and our position that relationship orientation largely evolved out of market orientation, renders it conceivable that such a relationship between relationship orientation and firm performance can be supported. In fact, the specific linkage between relationship orientation and firm performance has already been demonstrated (Lai et al., 2009; Palmatier et al., 2008; Taylor et al., 2008; Sin et al., 2005a; Cayanus \& Both-Butterfield, 2004; Hedaa \& Ritter, 2005; Strandholm et al., 2004; Sin et al., 2002). Based on these findings, we start by confirming this relationship between relationship orientation and firm performance in a South African context as we hypothesize that:

H1: Relationship orientation (RO) has a significant positive relationship with firm performance

\section{Innovation orientation}

Market orientation leads to incremental and trivial new product developments, and this is argued (Bennett \& Cooper, 1981) to be the rationale for innovation (innovation orientation) that has the potential to create markets and customers. Similarly, Berthon et al. (2004) cite Dickson (Dickson, 2000), who claims that consumption does not lead to production, as suggested by market orientation, providing even further motivation for firms to be innovative. Innovation orientation received more attention as the need for growth in increasingly competitive environments became dire and demand alone could no longer be relied on to provide opportunity for growth. According to Siguaw, Simpson and Enz (2006), the term innovation orientation has been frequently used in the innovation literature with mixed conceptualizations and meanings. Innovation orientation is defined (Siguaw et al., 2006) as the knowledge structure composed of a learning philosophy, strategic direction, and trans-functional beliefs within an organization that direct the organizational strategies and actions toward specific innovation-enabling competencies and processes. In addition, a number of studies (Simpson, Sigauw \& Enz, 2006; Zhou et al., 2005a; Zhou et al., 2005b; Deshpandé et al., 1997; Manu \& Sriram, 1996; Deshpandé et al., 1993; Manu, 1992; Capon, Farley \& Hoenig, 1990) have positively linked innovation to business performance. By contrast Simpson et al. (2006) argues that Progress in identifying outcomes of an innovation orientation has likely been hindered by three key obstacles: (a) a predominant reliance on a few, positive outcome measures, (b) a concentration on inputs, and (c) a bias toward positive results. While this contribution is important, a broader understanding of innovation effects is crucial and Simpson et al. (2006) concedes that a micro-level focus generally ignores effects of an innovation orientation on a firm's 
sustained financial performance. Therefore, in the South African context we hypothesize:

$\mathrm{H} 2$ : Innovation orientation (IO) has a significant positive relationship with firm performance

\section{Combining relationship and innovation orientation}

Beyond the direct relationship between innovation orientation and firm performance, research (Chen, Lin \& Chang, 2009; Cohen, 2008; Eiadat et al., 2008; Theoharakis \& Hooley, 2008; Zhou, Brown \& Dev, 2009; Hooley \& Greenley, 2005; Deshpandé \& Farley, 2004; Hooley et al., 2001; Hooley et al., 2000; Deshpandé, Farley \& Webster, 1992) has also suggested that innovation orientation mediates the relationship between market orientation and firm performance. This research suggests that innovative firms may employ new technologies and processes to enhance their marketing effectiveness. If it is then assumed that relationship orientation builds primarily on the idea of market orientation, it can be argued that innovation orientation should also mediate the relationship between a relationship orientation and firm performance. Moreover, we can then infer that innovation orientation mediates the relationship between trust, bonding, communication, shared values, empathy, reciprocity and firm performance. Therefore, we hypothesize that the relationship between each of the components of relationship orientation and firm performance is mediated by innovation orientation as follows:

H3: Innovation orientation mediates the relationship between trust and firm performance.

H4: Innovation orientation mediates the relationship between bonding and firm performance.

H5: Innovation orientation mediates the relationship between communication and firm performance.

H6 Innovation orientation mediates the relationship between shared values and firm performance.

H7: Innovation orientation mediates the relationship between empathy and firm performance.

H8: Innovation orientation mediates the relationship between reciprocity and firm performance.

According to Berthon et al. (2004), empirical evidence suggests that both innovation and market orientation have significant effects on corporate performance, and they noted that innovation orientation cannot be reduced to market orientation, or vice versa. Moreover, it is argued (Berthon, Hulbert \& Pitt, 1999) that if market orientation and innovation orientation are independent, potentially interacting constructs, then it is useful to integrate them. This lead the authors to construct a typology based on a two by two matrix of market orientation and innovation orientation, yielding four archetypes. The firms in the archetype labelled Isolate score low on both market and innovation orientation and are argued to exhibit little or no interaction between their innovation efforts and the target market, and tend to become the focus of their own attention - aptly described as "organocentric". These firms are typically obsessively concerned with internal efficiency and short-term profits. Firms in the Follow archetype score low on innovation and high on market orientation, indicating that these firms allow markets to drive innovation. They rely heavily on both formal and informal market research into products/services to propel their development. In the case of a Shape archetype, firms score high on innovation orientation and low on market orientation, implying that innovation shapes the market. These firms are primarily technology-oriented and their strategy is based on the principle that in certain circumstances innovation defines customer demand through providing new products or services. Finally, the Interact archetype contains firms that score high on both market and innovation orientations. Here a true "dialogue" (Berthon et al., 2004:1070) is established between the market and the firm's innovations. It implies that innovations are continuously tested against market needs, and are being used to create markets. We support the approach by Berthon, Hulbert and Pitt (1999) and extend the argument to relationship orientation. It is theorized that the Berthon et al. (1999) typology may be useful for integrating relationship orientation and innovation orientation in a similar manner. Because firms in the Isolate archetype are internally focused (organocentric), their relationship orientation is low. Similarly, because of the significant market (external) focus in the Follow archetype, relational issues dominate as these firms tend to allow customers to drive innovation in order to maintain good business relationships. In the Shape archetype the situation found in followers is just reversed as firms concentrate on innovation with less focus on relationships. In the Interact archetype, firms score high on both relationship and innovation orientations, and the interaction between both these orientations are frequent and intense. In this approach, market orientation is extended to relationship orientation (figure 1) and it is hypothesized that:

H9: There is a significant difference in firm performance between the strategic archetypes as defined by relationship orientation and innovation orientation.

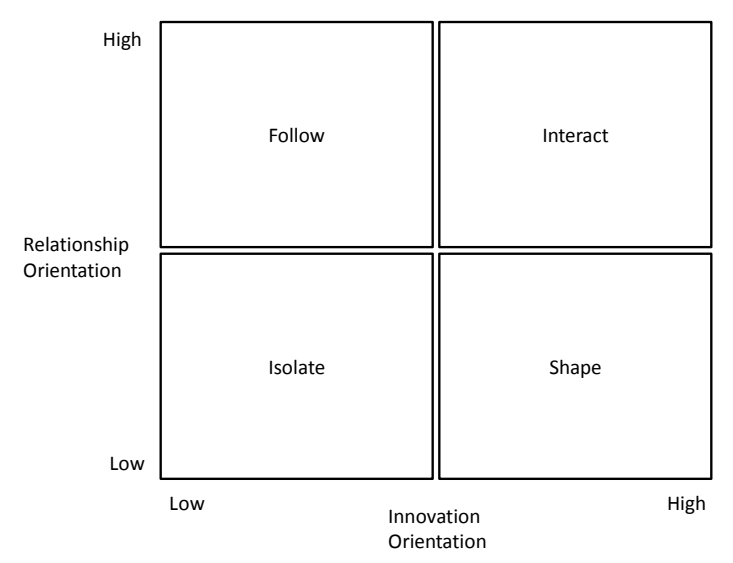

Source: Adapted from Berthon et al. (2004:1070)

Figure 1: Relationship-adjusted strategic orientation archetypes 


\section{Method}

The context for this research is the South African businessto-business environment, and the sample frame was defined as managers who operate primarily in a business-to-business environment, and who are involved in maintaining and/or creating relationships with suppliers and/or buyers. This meant that the respondents may represent firms that can either be involved in purely business markets or a mixture of business and consumer markets. Typically, in the case of consumer market activities, the respondent will be involved in supplier relations, such as in the case of a purchasing manager. A non-probability convenience sampling method, based on a commercial database of the researcher, was used to collected data from 250 firms in the metropolitan areas of Cape Town, Durban and Johannesburg. A multi-respondent method was employed because preliminary interviews revealed that opinions on relationships may vary in a single firm. The data were collected via a structured questionnaire that contained a reduced version (seven items) of the ICON scale proposed by Berthon et al. (2004) to measure innovation orientation, and the 22-item relationship orientation scale suggested by Sin et al. (2005b). It also included a 4-item firm performance scale containing perceptual measures for sales growth, customer retention, return on investment and market share as suggested by prevailing literature (Palmatier et al., 2007, Hart \& Banbury, 1994; Naman \& Slevin, 1993; Venkatraman \& Ramanujam, 1987; Dess \& Robinson Jr., 1984). Finally, the questionnaire contained some demographic questions relating to both respondents and the firms they represent.

All three scales were subjected to reliability analysis (Cronbach, 1951) and validity analysis using confirmatory factor analysis (CFA) in structural equations modelling (Jöreskog \& Sörbom, 1999b). Once the reliability and validity of the scale were confirmed, we proceeded with testing the hypotheses as indicated in Table 1.

\section{Results}

Of the 250 questionnaires distributed to respondents, only $181(72,4 \%)$ were regarded as suitable for analysis. Table 2 summarises the descriptive statistics of the sample.

Table 1: Research hypothesis and corresponding method of analysis

\begin{tabular}{l|c}
\hline \multicolumn{1}{c}{ Hypothesis } & Analysis \\
\hline H1: Relationship orientation (RO) has a significant positive relationship with firm performance. & SEM* \\
H2: Innovation orientation (IO) has a significant positive relationship with firm performance. & SEM \\
H3: An innovation orientation mediates the relationship between trust and firm performance. & PLS** \\
H4: An innovation orientation mediates the relationship between bonding and firm performance. & PLS \\
H5: An innovation orientation mediates the relationship between communication and firm performance. & PLS \\
H6: An innovation orientation mediates the relationship between shared value and firm performance. & PLS \\
H7: An innovation orientation mediates the relationship between empathy and firm performance. & PLS \\
H8: An innovation orientation mediates the relationship between reciprocity and firm performance. & PLS \\
H9: There is a significant difference in firm performance between the strategic archetypes as defined by & ANOVA*** \\
relationship orientation and innovation orientation. & \\
\hline
\end{tabular}
relationship orientation and innovation orientation.

*SEM = Structural Equation Modelling (Jöreskog and Sörbom, 1999a)

**PLS = Partial Least Squares (Ringle et al., 2005)

*** ANOVA $=$ Analysis of Variance(Palant, 2007)

\section{Table 2: Summary of key descriptive statistics}

\begin{tabular}{|c|c|}
\hline $\mathrm{N}$ & 181 \\
\hline$\%$ Respondents from locally owned firms & $64 \%$ \\
\hline$\%$ of sales generated from South African Markets & $98 \%$ \\
\hline \multicolumn{2}{|c|}{ Major Standard Industrial Classification (SIC) categories: } \\
\hline Wholesale Trade & $34 \%$ \\
\hline Financial Services - (Intermediation) & $50 \%$ \\
\hline Manufacturing & $4 \%$ \\
\hline Transportation & $6 \%$ \\
\hline Other ( 6 categories) & $6 \%$ \\
\hline \multicolumn{2}{|l|}{ Managerial position of respondents: } \\
\hline Top management & $11 \%$ \\
\hline Middle Management & $33 \%$ \\
\hline $1^{\text {st }}$ tier management & $42 \%$ \\
\hline \multicolumn{2}{|l|}{ Functional deployment: } \\
\hline Marketing and Sales Management & $45 \%$ \\
\hline Financial Management & $14 \%$ \\
\hline Operational Management & $11 \%$ \\
\hline \multicolumn{2}{|l|}{ Firm size by number of employees: } \\
\hline$\%<300$ & $45 \%$ \\
\hline$\%>5000$ & $31 \%$ \\
\hline Average respondent age (years) & $31-40$ \\
\hline$\%$ Male respondents & $48 \%$ \\
\hline$\%$ Female respondents & $52 \%$ \\
\hline
\end{tabular}


The Cronbach's alpha coefficient, a mean reliability coefficient calculated from all possible split-half partitions of the measurement scale, was employed to consider internal reliability of each scale. The overall reliability for all three scales was satisfactory $(\alpha>0,7)$ and these are reported in Table 3. In the relationship orientation scale, one dimension (communication) appeared not to be reliable in a South African context, and this raised reason to consider the elimination of this dimension.

Construct validity was considered through the use of confirmatory factor analysis in structural equation modelling (SEM). According to Hair et al. (2006), structural equation modelling tests the extent to which the researcher's a priori pattern is represented in the data and allows the researcher the opportunity to consider multiple observed variables. Structural equation modelling explicitly takes measurement error into account and gives greater recognition to measurement constructs. Table 4 reports the summarised CFA results for each scale.

From table 4 it is evident that the data do not fit (RMSEA > 0.08) the theorized model proposed by the relationship orientation scale. In accordance with the literature (Hair et al., 2006; Bentler et al., 2001; Bagozzi, 1981), the relationship orientation data were subjected to exploratory factor analysis to reconsider the underlying variable structure. This analysis suggested that only four factors - as opposed to six in Sin et al.'s (2005b) article - could be described on the basis of this measurement. Most items loaded as expected, but some items cross-loaded, while others exhibited weak $(<0,3)$ loadings. The result of this analysis was a revised 16-item scale of relationship orientation based on four latent variables labelled: Sharing (six items), Bonding (four items), Trust (three items) and Reciprocity (three items). The CFA for the revised RO scale yielded a weak but acceptable fit $\left(\chi^{2}=254,54, \mathrm{df}=100\right.$, $\mathrm{p}=0,000$, RMSEA $=0.09$ ) and it was decided to continue testing the hypothesized relationships based on this measurement. However, as a result of the refinement of the RO scale, H5 and H7 had to be excluded from the analysis. In addition, $\mathrm{H} 4$ now reflects the hypothesized relationship for the construct labelled "sharing" as follows:

H4: An innovation orientation mediates the relationship between sharing and firm performance.

To test $\mathrm{H} 1$ and $\mathrm{H} 2$, the relationship between IO and firm performance (Perf), and that between RO and Perf, was first tested separately and then simultaneously in a structural model. Table 5 shows the independent tests while figure 2 shows the result of the structural model when considering both constructs simultaneously.

Table 3: Reliability analysis

\begin{tabular}{|c|c|c|c|}
\hline & \multicolumn{2}{|c|}{ Latent Variables } & Cronbach Alpha \\
\hline Innovation Urientation (/ items) & & & 0,729 \\
\hline \multirow[t]{7}{*}{ Relationship Orientation (22 items) } & & $\beta$ & 0,891 \\
\hline & Trust & 0,703 & \\
\hline & Bonding & 0,763 & \\
\hline & Communication & 0,644 & \\
\hline & Shared Value & 0,864 & \\
\hline & Empathy & 0,791 & \\
\hline & Reciprocity & 0,662 & \\
\hline
\end{tabular}

Table 4: Confirmatory Factor Analysis

\begin{tabular}{lcccc}
\hline \multicolumn{1}{c}{ Scale } & $\chi^{2}$ & df & RMSEA $^{*}$ & $\rho$ \\
\hline Innovation Orientation (IO) & 25,46 & 14 & 0,067 & 0,030 \\
Relationship Orientation (RO) & 611,68 & 206 & 0,105 & 0,000 \\
Firm Performance (Perf) & 3,16 & 2 & 0,057 & 0,205 \\
\hline
\end{tabular}

* Root Mean Square Error of Approximation

Table 5: Independent tests of relationship between IO, RO and firm performance

\begin{tabular}{|c|c|c|c|c|}
\hline Relationship & $\chi^{2}$ & $\mathrm{df}$ & RMSEA* & $\rho$ \\
\hline $\mathrm{IO} \rightarrow$ Perf & 90,42 & 43 & 0,78 & 0,000 \\
\hline $\mathrm{RO} \rightarrow$ Perf & 32,22 & 19 & 0,06 & 0,029 \\
\hline
\end{tabular}

* Root Mean Square Error of Approximation 
Considering the relationship between IO and RO with firm performance simultaneously (Figure 2) yielded an acceptable (but weaker) fit $\left(\chi^{2}=52,37, \mathrm{df}=24, \mathrm{p}=0,000\right.$, RMSEA $=0,08)$. Moreover, both these analyses confirm that there is a significant positive relationship between innovation orientation and firm performance, as well as between relationship orientation and firm performance, thus that $\mathrm{H} 1$ and $\mathrm{H} 2$ are supported.

To test the mediating effect of innovation orientation on relationship orientation, we employed partial least squares (PLS) by using the SmartPLS (Ringle, Wende \& Will, 2005) software. In PLS, X-variables (the predictors) are reduced to principal components, as are the Y-variables (the dependents). The components of $\mathrm{X}$ are used to predict the scores on the Y-components, and the predicted Ycomponent scores are used to predict the actual values of the Y-variables (Wold, 1985). In constructing the principal components of $\mathrm{X}$, the PLS algorithm iteratively maximizes the strength of the relation of successive pairs of $\mathrm{X}$ - and $\mathrm{Y}$ component scores by maximizing the covariance of each $\mathrm{X}$ - score with the Y-variables. This strategy means that while the original $\mathrm{X}$-variables may be multi-collinear, the $\mathrm{X}$ components used to predict $\mathrm{Y}$ will be orthogonal. Also, the $\mathrm{X}$-variables may have missing values, but there will be a computed score for every case on every X-component. The advantages of PLS include the ability to model multiple dependents, as well as multiple independents; the ability to handle multi-collinearity among the independents; robustness in the face of data noise and missing data; and the creation of independent latent variables directly on the basis of cross-products involving the response variable(s), making for stronger predictions. Disadvantages of PLS include greater difficulty in interpreting the loadings of the independent latent variables (which are based on crossproduct relations with the response variables, instead of, as in common factor analysis, on covariances among the manifest independents), and because the distributional properties of estimates are not known, the researcher cannot assess significance except through bootstrap induction (Fornell \& Cha, 1994; Fornell \& Bookstein, 1982). Table 6 reports the results from this analysis.

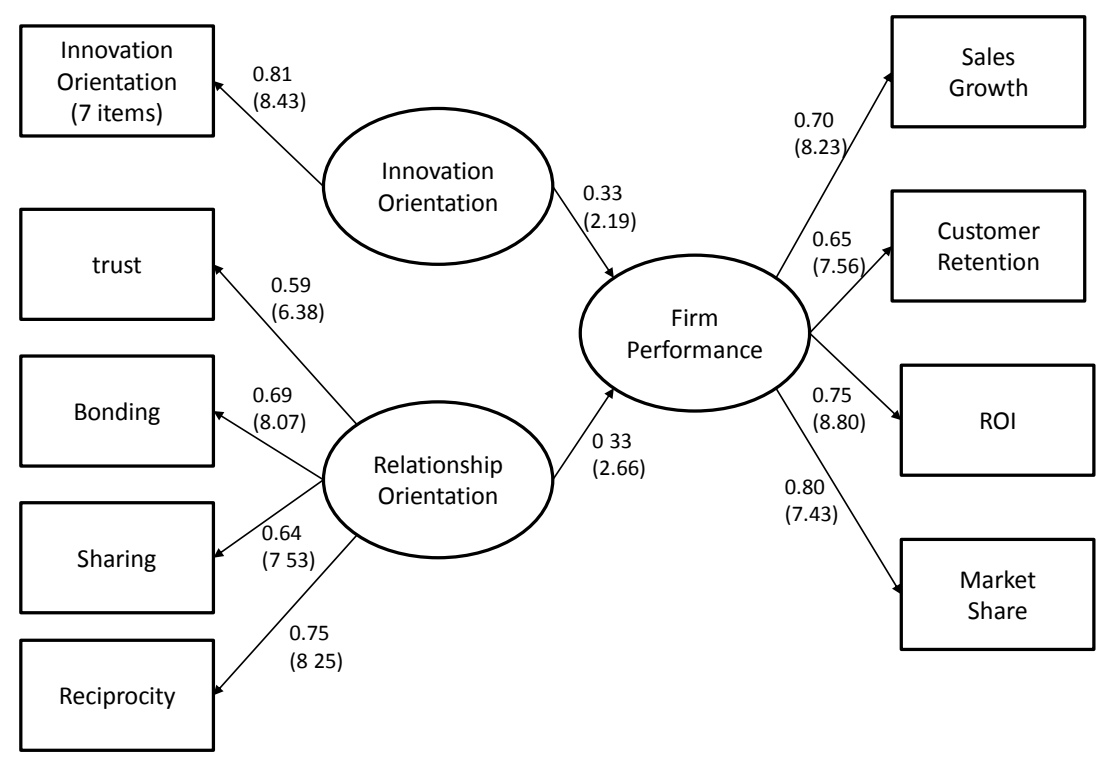

Figure 2: Structural model for innovation orientation, relationship orientation and firm performance. ( $\beta$-coefficients and $t$-vales in parenthesis)

Table 6: Test for mediation

\begin{tabular}{|c|c|c|c|c|c|c|c|}
\hline & \multirow{2}{*}{ AVE } & \multirow{2}{*}{$\begin{array}{l}\text { Composite } \\
\text { Reliability }\end{array}$} & \multirow{2}{*}{$\mathbf{R}^{2}$} & \multirow{2}{*}{$\begin{array}{c}\text { Cronbach's } \\
\text { Alpha }\end{array}$} & & \multicolumn{2}{|c|}{ Total Effect } \\
\hline & & & & & & $\beta$ & $t$-value \\
\hline \multicolumn{8}{|l|}{ Trust } \\
\hline IO & 0,409 & 0,821 & 0,148 & 0,744 & Trust $\rightarrow \mathrm{IO}$ & 0,368 & 5,304 \\
\hline Perf & 0,610 & 0,862 & 0,161 & 0,791 & $\mathrm{IO} \rightarrow$ Perf & 0,416 & 6,746 \\
\hline trust & 0,766 & 0,907 & - & 0,848 & Trust $\rightarrow$ Perf & $-0,042$ & $0,439 *$ \\
\hline \multicolumn{8}{|c|}{ Sharing (Share) } \\
\hline IO & 0,402 & 0,819 & 0,061 & 0,744 & Share $\rightarrow \mathrm{IO}$ & 0,248 & 2,452 \\
\hline Perf & 0,612 & 0,862 & 0,202 & 0,791 & $\mathrm{IO} \rightarrow$ Perf & 0,370 & 6,307 \\
\hline Share & 0,570 & 0,887 & - & 0,851 & Share $\rightarrow$ Perf & 0,181 & 2,444 \\
\hline \multicolumn{8}{|c|}{ Bonding (Bond) } \\
\hline IO & 0,410 & 0,821 & 0,250 & 0,744 & Bond $\rightarrow \mathrm{IO}$ & 0,511 & 8,757 \\
\hline Perf & 0,608 & 0,860 & 0,170 & 0,791 & $\mathrm{IO} \rightarrow$ Perf & 0,346 & 5,141 \\
\hline Bond & 0,734 & 0,892 & - & 0,823 & Bond $\rightarrow$ Perf & 0,111 & $1,436^{*}$ \\
\hline \multicolumn{8}{|c|}{ Reciprocity (Recip) } \\
\hline IO & 0,405 & 0,821 & 0,179 & 0,744 & Recip $\rightarrow$ IO & 0,423 & 5,899 \\
\hline Perf & 0,609 & 0,861 & 0,213 & 0,791 & $\mathrm{IO} \rightarrow$ Perf & 0,314 & 4,580 \\
\hline Recip & 0,597 & 0,816 & - & 0,667 & Recip $\rightarrow$ Perf & 0,231 & 3,041 \\
\hline
\end{tabular}

Perf $=$ Firm Performance, $*=$ not significant at $95 \%$ level, AVE = Average Variance Extracted 
Consistent with existing Innovation and Market Orientation theory, our results (Table 6) showed a mediating effect of innovation orientation on the relationship between all four of the relationship orientation measures and perceptual measures of firm performance. In the case of trust and bonding, full mediation is evident, while in the case of sharing and reciprocity, only partial mediation is observed. These results confirm support for hypotheses 3 to 8 (H3, H4, H6 and H8).

In order to test the final hypothesis that deals with differences between the archetypes suggested by Berthon et al. (2004), a median intersection approach was used to categorize respondents according to their overall relationship orientation and innovation orientation scores (as suggested by figure 1). On the bases of this categorization, performance scores were compared. Tables 7 and 8 report the results of this analysis.

From the table it is noted that the majority (47\%) of respondents consider their firms to be in the Isolate category which is neither high on relationship orientation, nor on innovation orientation. Furthermore, the best performing firms (as rated by respondents) find themselves in the Interact archetype for all the performance measures except sales growth. Inversely, firms rated in the Isolate archetype consistently perform the worst across all the performance measures. This observation provides further support for the Berthon et al. (2004) scheme and demonstrates its usefulness in a different context. Results of an ANOVA analysis (Table 8) indicate a significant difference in the performance measures between archetypes, except for Market Share where no significant difference was observed. Hence, H9 is partially well-supported.

The ANOVA analysis also indicated that the significant differences between "Isolators" and "Interactors" was observed for sales growth $(\mathrm{p}=0.025)$, customer retention $(p=0.000)$ and ROI $(p=0.000)$. Moreover, in terms of customer retention, "Interactors" also differ significantly from "Shapers" $(p=0.000)$ and "Followers" $(p=0.010)$. Finally, a significant difference for ROI $(\mathrm{p}=0.040)$ between "Interactors" and "Followers" could also be observed.

Table 7: Mean performance scores by strategic orientation archetype

\begin{tabular}{|c|c|c|c|c|c|c|c|c|c|c|c|c|}
\hline & \multirow[b]{2}{*}{$\mathrm{N}$} & \multirow[b]{2}{*}{$\%$} & \multicolumn{2}{|c|}{$\begin{array}{l}\text { Sales } \\
\text { Growth }\end{array}$} & \multicolumn{2}{|c|}{$\begin{array}{l}\text { Customer } \\
\text { Retention }\end{array}$} & \multicolumn{2}{|c|}{ ROI } & \multicolumn{2}{|c|}{$\begin{array}{l}\text { Market } \\
\text { Share }\end{array}$} & \multicolumn{2}{|c|}{$\begin{array}{c}\text { Overall } \\
\text { Performance }\end{array}$} \\
\hline & & & Mean & Rank & Mean & Rank & Mean & Rank & Mean & Rank & Mean & Rank \\
\hline Interact & 38 & 21,0 & 5,62 & 3 & 6,24 & 1 & 6,16 & 1 & 5,63 & 1 & \begin{tabular}{|l}
5,99 \\
\end{tabular} & 1 \\
\hline Follow & 36 & 19,9 & 6,00 & 1 & 5,89 & 2 & 5,69 & 3 & 5,50 & 2 & 5,77 & 2 \\
\hline Shape & 22 & 12,2 & 5,59 & 2 & 5,45 & 3 & 5,91 & 2 & 5,32 & 3 & 5,66 & 3 \\
\hline Isolate & 85 & 47,0 & 5,51 & 4 & 5,44 & 4 & 5,42 & 4 & 5,18 & 4 & 5,39 & 4 \\
\hline
\end{tabular}

Table 8: ANOVA results (F-statistic) for strategic archetypes

\begin{tabular}{lcc}
\hline & & $\mathrm{P}$ \\
Sales Growth & $\mathrm{F}$ & 0,017 \\
Customer retention & 3,488 & 0,000 \\
ROI & 9,862 & 0,000 \\
Market Share & 7,990 & $0,138^{*}$ \\
Overall Performance & 1,861 & 0,000 \\
\hline
\end{tabular}

$*$ Not significant at $95 \%(\mathrm{p}<0,05)$ level

\section{Discussion}

Several studies have examined the relationship between strategic orientations and business performance in economies that can be regarded as emerging or transitional, but most of the research in this area remains within developed countries. This leaves the generalizability and boundary conditions of the findings open for interrogation in other contexts. To complicate matters further, Gao et al. (2007) suggest that the effects of strategic orientations may be robust in relatively homogenous contexts of developed countries, but a more dynamic context is needed to examine these in developing market contexts. In this study we have attempted to test the relationship between strategic orientations in a context different from what they were conceived in. While the adjusted measure we used for measuring innovation orientation exhibits good reliability and validity, the same cannot be said for relationship orientation in a South African context. The result was a revised measure of relationship orientation, and although this revision served the purpose of this study, we acknowledge that it needs significant refinement based on primary research in this particular context.

The fact that more refined measures need to be developed to match the South African context cannot dispel the importance of innovation and relationship orientation. This study demonstrates a significant positive relation between innovation orientation and performance, as well as between relationship orientation and performance. In addition, our research showed the mediating effect of innovation orientation on the relationship between relationship orientation and firm performance. Our results also suggest that higher levels of performance are possible for firms that achieve an increased integration of innovation and relationship orientation. Likewise, firms that score low on both these orientations perform worse. Therefore, we posit that business-to-business firms need both an innovation orientation, as well as a relationship orientation. By integrating these strategic orientations, firms may enhance their performance beyond what may be possible by adoption only one of the orientations. 


\section{Limitations and further research}

This study is limited in a number of ways of which the most notable is the absence of a random sample. Because we had to rely on a non-probability sample, our findings remain of an explorative nature with limited generalizability. Secondly, the use of perceptual measures of performance may bring various limitations, such as common method bias, into consideration. A more robust measure of firm performance (possibly an objective measure) should enhance the quality of the findings. Finally, other research (Zhou et al., 2005b; Srinivasan, Lilien \& Rangaswamy, 2002; Gao et al., 2007) suggests that technology orientation might represent an alternative for a similar study. We are concerned that, in general, respondents may easily confuse the definitions of technology and innovation and this may yield a bias response.

According to Zhou et al. (2005b) an overemphasis on customers could lead to trivial innovations and myopic research and development $(\mathrm{R} \& \mathrm{D})$, which might lower the firm's innovative competence. Consequently, it can be argued that market-oriented firms may risk losing the foresight of innovating creatively in their attempt to serve customers' existing needs (Hamel, 2002). These observations amplify the need for research that attempts to consider multiple strategic orientations. We posit that by considering various strategic orientations simultaneously, a combined effect may be observed, such as demonstrated by Berthon et al. (2004), Gao et al. (2007) and others. This will advance the research questions on strategic orientation to those of a portfolio question and how firms may shift their focus in orientation according to environmental demands, as opposed to which "singular" strategic orientation will yield the greatest benefit for the firm.

\section{References}

Atuahene-Gima, K. 1996. 'Market orientation and innovation', Journal of Business Research, 35(10): 93-103.

Au, A.K. M. \& Tse, A.C.B. 1995. 'The effect of marketing orientation on company performance in the service sector: A comparative study of the hotel industry in Hong Kong and New Zealand', Journal of International Consumer Marketing, 8(2):77-88.

Bagozzi, R.P. 1981. 'Evaluating structural equation models with unobserbed variables and measurement error: A comment', Journal of Marketing Research, 43(3):375-381.

Bennett, R. \& Cooper, R.C. 1981. 'Beyond the marketing concept', Business Horizons, 24(3):76-83.

Bentler, P.M., Bagozzi, R.P., Cudeck, R., Cote, J., Netemeyer, R., Lehmann, D. R., McDonald, R., Heath, T. \& Irwin, J. 2001. 'Structural equations modeling', Journal of Consumer Psychology, 10(1/2):83-201.

Berthon, P., Hulbert, J.M. \& Pitt, L.F. 1999. 'To serve or create? Strategic orientations toward customers and innovation', California Management Review, 42(1):37-56.
Berthon, P., Hulbert, J.M. \& Pitt, L. 2004. 'Innovation or customer orientation? An empirical investigation', European Journal of Marketing, 38(9/10):1065-1090.

Camarero, C. 2007. 'Relationship orientation or service quality? What is the trigger of performance in financial and insurance services?' International Journal of Bank Marketing, 25(6):406-426.

Camelo-Ordaz, C., Martin-Alcazar, F. \& Valle-Cabrera, R. 2003. 'Intangible resources and strategic orientation of companies: An analysis in the Spanish context', Journal of Business Research, 56(1):95-103.

Capon, N., Farley, J.U. \& Hoenig, S. 1990. 'Determinants of financial performance: A meta-analysis', Management Science, 36(10):1143-1159.

Cayanus, J.L. \& Both-Butterfield, M. 2004. 'Relationship orientation, jealousy, and equity: An examination of jealousy evoking and positive communicative responses', Communication Quarterly, 52(3):237-250.

Chen, Y.-S., Lin, M.-J. J. \& Chang, C.-H. 2009. 'The positive effects of relationship learning and absorptive capacity on innovation performance and competitive advantage in industrial markets', Industrial Marketing Management, 38(2):152-158.

Cohen, J.F. 2008. 'Contextual determinants and performance implications of information systems strategy planning within South African firms', Information \& Management, 45(8):547-555.

Cronbach, L. 1951. 'Coefficient alpha and the internal structure of tests', Psychometrika, 16(3):297-334.

Day, G.S. \& Wensley, R. 1983. 'Marketing theory with strategic orientation', Journal of Marketing, 47(3):79-89.

Deshpandé, R. \& Farley, J.U. 2000. 'Triad lessons: Generalizing results on high performance firms in five business-to-business markets', International Journal of Research in Marketing, 17(4):353-362.

Deshpandé, R. \& Farley, J.U. 2004. 'Organizational culture, market orientation, innovativeness, and firm performance: An international research odyssey', International Journal of Research in Marketing, 21(1):3-22.

Deshpandé, R., Farley, J.U. \& Bowman, D. 2004. 'Tigers, dragons, and others: Profiling high performance in Asian firms', Journal of International Marketing, 12(3):5-29.

Deshpandé, R., Farley, J.U. \& Webster J.R.., F.E. 1992. Corporate culture, customer orientation, innovativeness in Japanese firms. Marketing Science Institute Working Paper Series. Cambridge, Massachusetts, Marketing Science Institute.

Deshpandé, R., Farley, J.U. \& Webster JR., F.E. 1993. 'Corporate culture, customer orientation, and innovativeness 
in Japanese firms: A quadrad analysis', Journal of Marketing, 57(1):23-27.

Deshpandé, R., Farley, J.U. \& Webster JR., F.E. 1997. Factors affecting organizational performance: A five country comparison, Marketing Science Institute Working Paper Series. Cambridge, Massachusetts, Marketing Science Institute.

Dess, G. G. \& Robinson JR., R.B. 1984. 'Measuring organizational performance in the absence of objective measures', Strategic Management Journal, 5(3):265-273.

Dickson, P.R. 2000. 'Understanding the trade winds: The global evolution of production, consumption, and the Internet', Journal of Consumer Research, 27(1):115-122.

Dobni, B.C. \& Luffman, G. 2000. 'Market orientation and market strategy profiling: An empirical test of environmentbehaviour-action co-alignment and its performance implications', Management Decision, 38(8):503-519.

Doyle, P. \& Hooley, G.J. 1992. 'Strategic orientation and corporate performance', International Journal of Research in Marketing, 9(1):59-74.

Eiadat, Y., Kelly, A., Roche, F. \& Eyadat, H. 2008. 'Green and competitive? An empirical test of the mediating role of environmental innovation strategy', Journal of World Business, 43(2):131-145.

Fill, C. \& Fill, K.E. 2005. Business to business marketing: Relationships, systems and communications. Harlow, UK. FT Prentice Hall.

Fornell, C. \& Bookstein, F.L. 1982. 'Two structural equation models: LISREL and PLS applied to consumer exit-voice theory', Journal of Marketing Research, 19(4):440-452.

Fornell, C. \& Cha, J. 1994. 'Partial least squares'. In Bagozzi, R. P. (Ed.). Advanced methods of marketing research. Cambridge, Massachusetts: Blackwell Business.

Gao, G.Y., Zhou, K.Z. \& Yim, C.K. 2007. 'On what should firms focus in transitional economies? A study of the contingent value of strategic orientations in China', International Journal of Research in Marketing, 24(1):3-15.

Gatignon, H. \& Xuereb, J.M. 1997. 'Strategic orientation of the firm and new product performance', Journal of Marketing Research, 34(1):77-90.

Golden, P.A., Johnson, D.M. \& Smith, J. R. 1995. 'Strategic orientation and marketing strategies in transition economies: A study of Russian firms', Journal of Strategic Marketing, 3(1):1-22.

Grönroos, C. 1989. 'Defining marketing: A market-oriented approach', European Journal of Marketing, 23(1):52-60.
Gruen, T.W. 1995. 'The outcome set of relationship marketing in consumer markets', International Business Review, 4(4):447-469.

Hair, J.F., Black, W.C., Babin, B., Anderson, R.E. \& Tatham, R.L. 2006. Multivatiate data analysis. Upper Saddle River, USA: Pearson Prentice Hall.

Hamel, G. 2002. Leading the revolution. Boston, MA: Harvard Business School Press.

Hart, S. \& Banbury, C. 1994. 'How strategy-making processes can make a difference', Strategic Management Journal, 15(4):251-269.

Heath, T. \& Irwin, J. 2001. 'Structural equations modeling', Journal of Consumer Psychology, 10(1/2):83-201.

Hedaa, L. \& Ritter, T. 2005. 'Business relationships on different waves: Paradigm shift and marketing orientation revisited', Industrial Marketing Management, 34(7):714721.

Hooley, G.J., Cox, T., Fahy, J., Shipley, D., Beracs, J., Fonfara, K. \& Snoj, B. 2000. 'Market orientation in the transition economies of Central Europe: Tests of the Narver and Slater Market Orientation Scales', Journal of Business Research, 50(3):273-285.

Hooley, G.J. \& Greenley, G.E. 2005. 'The resource underpinnings of competitive positions', Journal of Strategic Marketing, 13(2):93-116.

Hooley, G.J., Greenley, G.E., Fahy, J. \& Cadogan, J.W. 2001. 'Market-focused resources, competitive positioning and firm performance', Journal of Marketing Management, 17(5/6):503-520.

Jöreskog, K.G. \& Sörbom, D. 1999a. LISREL 8: A guide to the program and applications. Lincolnwood, Illinois: Scientific Software International, Inc.

Jöreskog, K.G. \& Sörbom, D. 1999b. Structural equation modeling with the SIMPLIS command language. Lincolnwood, Illinois: Scientific Software International, Inc.

Kohli, A.K. \& Jaworski, B.J. 1990. 'Market orientation: The construct, research propositions, and managerial implications. Marketing Science Institute Working Paper Series. Cambridge, Massachusetts: Marketing Science Institute.

Klemz, B.R., Boshoff, C. \& Mazibuko, N.-E. 2006. 'Emerging markets in black South African townships: Small local independently owned versus large national retailers', European Journal of Marketing, 40(5/6):590-610.

Laforet, S. 2008. 'Size, strategic, and market orientation affects on innovation', Journal of Business Research, 61(7):753-764. 
Lai, C.-S. 2009. 'The use of influence strategies in interdependent relationship: The moderating role of shared norms and values', Industrial Marketing Management, 38: 426-432.

Lai, C.-S., Pai, D.-C., Yang, C.-F. \& Lin, H.-J. 2009. 'The effects of market orientation on relationship learning and relationship performance in industrial marketing: The dyadic perspectives', Industrial Marketing Management, 38(2):166-172.

Leskovar-Spacapan, G. \& Bastic, M. 2007. 'Differences in organizations' innovation capability in transition economy: Internal aspect of the organizations' strategic orientation', Technovation, 27(9):533-546.

Luo, Y. \& Park, S.H. 2001. 'Strategic alignment and performance of market-seeking MNCs in China', Strategic Management Journal, 22(2):141-155.

Manu, F.A. 1992. 'Innovation orientation, environment and performance: A comparison of U.S. and European markets', Journal of International Business Studies, 23(2):333-359.

Manu, F.A. \& Sriram, V. 1996. 'Innovation, marketing strategy, environment, and performance', Journal of Business Research, 35(1):79-91.

Mckee, D.O., Varadarajan, P.R. \& Pride, W.M. 1989. 'Strategic adaptability and firm performance: A marketcontingent perspective', Journal of Marketing, 53(3):21-35.

Miles, R.E. \& Snow, C.C. 1978. Organisational strategy, structure and process. New York: McGraw-Hill Book Company.

Morgan, R.E. \& Strong, C.A. 1998. 'Market orientation and dimensions of strategic orientation', European Journal of Marketing, 32(11/12):1015-1023.

Morgan, R.E. \& Strong, C.A. 2003. 'Business performance and dimensions of strategic orientation', Journal of Business Research, 56(2):163-176.

Morgan, R.M. \& Hunt, S.D. 1994. 'The commitment-trust theory of relationship marketing', Journal of Marketing, 58(July):20-38.

Moses, A. 2007. 'Managerial social capital, strategic orientation, and organizational performance in an emerging economy', Strategic Management Journal, 28(12):12351255 .

Naman, J.L. \& Slevin, D.P. 1993. 'Entrepreneurship and the concept of fit: A model and empirical tests', Strategic Management Journal, 14(2):137-153.

Narver, J.C. \& Slater, S.F. 1990. 'The effect of a market orientation on business profitability', Journal of Marketing, 54(4):20-35.

Noble, C.H., Sinha, R.K. \& Kumar, A. 2002. 'Market orientation and alternative strategic orientations: A longitudinal assessment of performance implications', Journal of Marketing, 66(4):25-39.

Palant, J. 2007. SPSS survival manual. Glasgow, UK: McGraw-Hill.

almatier, R. 2007. 'What drives customer relationship value in business-to-business exchanges?' Marketing Science Institute Report, 4(7):07-118.

Palmatier, R., Scheer, L., Evans, K. \& Arnold, T. 2008. 'Achieving relationship marketing effectiveness in businessto-business exchanges', Journal of the Academy of Marketing Science, 36(2):174-190.

Palmatier, R.W., Dant, R.P. \& Grewal, D. 2007. 'A comparative longitudinal analysis of theoretical perspectives of interorganizational relationship performance', Journal of Marketing, 71(4):172-194.

Pleshko, L. \& Nickerson, I. 2008. 'Strategic orientation, organizational structure, and the associated effects on performance in industrial firms', Academy of Strategic Management Journal, 7(16):95.

Rajagopalan, N. 1997. 'Strategic orientations, incentive plan adoption, and firm performance: Evidence from electronic utility firms', Strategic Management Journal, 18(10):761785 .

Ramani, G. \& Kumar, V. 2008. 'Interaction orientation and firm performance,' Journal of Marketing, 72(1):27-45.

Ringle, C., Wende, S. \& Will, A. 2005. 'SmartPLS 2.0 (beta)'. [online] URL: http://www.smartplas.de.

Robinson J.R., R.B. \& Pearce II, J.A. 1988. 'Planned patterns of strategic behavior and their relationship to business-unit performance', Strategic Management Journal, 9(1):43-60.

Santos-Vijande, M.L., Sanzo-Pérez, M.J., ÁlvarezGonzáles, L.I. \& Vásquez-Casielles, R. 2005. 'Effects of market orientation on business strategic behaviour', Journal of Strategic Marketing, 13(1):17-42.

Siguaw, J.A., Simpson, P.M. \& Enz, C.A. 2006. 'Conceptualizing innovation orientation: A framework for study and integration of innovation research,' Journal of Product Innovation Management, 23(6):556-574.

Simpson, P.M., Siguaw, J.A. \& Enz, C.A. 2006. 'Innovation orientation outcomes: The good and the bad', Journal of Business Research, 59(10/11):1133-1141.

Sin, L.Y.M., Tse, A.C.B., Yau, O.H.M., Chow, R.P.M. \& Lee, J.S.Y. 2005a. 'Market orientation, relationship marketing orientation, and business performance: The moderating effects of economic ideology and industry type', Journal of International Marketing, 13(7):36-57.

Sin, L.Y.M., Tse, A.C.B., Yau, O.H.M., Chow, R.P.M., Lee, J.S.Y. \& Lau, L.B.Y. 2005b. 'Relationship marketing 
orientation: Scale development and cross-cultural validation', Journal of Business Research, 58(2):185-194.

Sin, L.Y.M., Tse, A.C.B., Yau, O.H.M., Lee, J.S.Y. \& Chow, R. 2002. 'The effect of relationship marketing orientation on business performance in a service-oriented economy', Journal of Services Marketing, 16(1):656-676.

Srinivasan, R., Lilien, G.L. \& Rangaswamy, A. 2002. 'Technological opportunism and radical technology adoption: An application to e-business', Journal of Marketing, 66(3):47-68.

Stanko, M.A., Bonner, J.M. \& Calantone, R.J. 2007. 'Building commitment in buyer-seller relationships: A tie strength perspective', Industrial Marketing Management, 36, 1094-1103.

Strandholm, K., Kumar, K. \& Subramanian, R. 2004. 'Examining the interrelationships among perceived environmental change, strategic response, managerial characteristics, and organisational performance', Journal of Business Research, 57(1):58-68.

Taylor, C.R., Kim, K.H., Ko, E., Park, M.H., Kim, D.R. \& Moon, H.I. 2008. 'Does having a market orientation lead to higher levels of relationship commitment and business performance? Evidence from the Korean robotics industry', Industrial Marketing Management, 37(7):825-832.

Terblanche, N.S. 2005. 'A century of marketing: Achievements, mishaps and future challenges', Management Dynamics Volume, 14(4):2-17.

Theoharakis, V. \& Hooley, G. 2008. 'Customer orientation and innovativeness: Differing roles in new and old Europe', International Journal of Research in Marketing, 25(1):6979.

Theron, E., Terblanche, N.S. \& Boshoff, C. 2008. 'The antecedents of relationship commitment in the management of relationships in business-to-business (B2B) financial services', Journal of Marketing Management, 24:997-1010.

Tse, A.C.B., Sin, L.Y.M., Yau, O.H.M., Lee, J.S.Y. \& Chow, R. 2003. 'Market orientation and business performance in a Chinese business environment', Journal of Business Research, 56(3):227-239.

Venkatraman, N. 1989. 'Strategic orientation of business enterprises: The construct, dimensionality and measurement', Management Science, 35(8):942-962.

Venkatraman, N. \& Ramanujam, V. 1987. 'Measurement of business economic performance: An examination of method convergence', Journal of Management, 13(1):109.

Voss, G.B. \& Voss, Z.G. 2000. 'Strategic orientation and firm performance in an artistic environment', Journal of Marketing, 64(1):67-83.
Wang, C.L. 2007. 'Guanxi vs. relationship marketing: Exploring underlying differences', Industrial Marketing Management, 36:81-86.

Winklhofer, H., Pressey, A. \& Tzokas, N. 2006. 'A cultural perspective of relationship orientation: Using organisational culture to support a supply relationship orientation', Journal of Marketing Management, 22:69-194.

Wold, H. 1985. 'Partial least squares'. In Kotz, S. \& Johnson, N.L. (Eds.). Encyclopedia of statistical sciences, 6:581-591.

Wright, P., Kroll, M., Pray, B. \& Lado, A. 1995. 'Strategic orientations, competitive advantage, and business performance', Journal of Business Research, 33(2):143-151.

Zhou, K.Z., Brown, J.R. \& Dev, C.S. 2009. 'Market orientation, competitive advantage, and performance: A demand-based perspective', Journal of Business Research, 62(11):1063-1070.

Zhou, K.Z., Gao, G.Y., Yang, Z. \& Zhou, N. 2005a. 'Developing strategic orientation in China: Antecedents and consequences of market and innovation orientations', Journal of Business Research, 58(2):1049-1058.

Zhou, K.Z., Yim, C.K. \& Tse, D.K. 2005b. 'The effects of strategic orientations on technology- and market-based breakthrough innovations', Journal of Marketing, 69(8):4260 . 